\section{Vessel Volume, Gelling Agent, and Basal Salts Affect pH and Gel Strength of Autoclave Tissue Culture Media}

\author{
Hazel Y. Wetzstein, Choongsik Kim, and Harry E. Sommer ${ }^{1}$ \\ Department of Horticulture, Plant Science Building, University of Georgia, \\ Athens, GA 30602-7273
}

Additional index words. agar, gellan gum, medium matrix

\begin{abstract}
Effects of autoclaving volume, gelling agent (Bactoagar, Gel-gro, Phytagar), and basal salts [Murashige and Skoog (MS); Woody Plant Medium (WPM); Gamborg B5 (GB)] on gel strength and $\mathrm{pH}$ of tissue culture media were tested. Gel strength was significantly affected by gelling agent and basal medium. MS media were generally softer than comparable WPM or GB media. As the vessel volume during autoclaving decreased, gel strength significantly decreased with Phytagar and Bactoagar gelling agents; Gel-gro had greater gel strength at the intermediate volume of medium autoclave. In all cases, autoclaving resulted in a $\mathrm{pH}$ decrease of 0.2 to $0.5 \mathrm{pH}$ units. Lower $\mathrm{pH}$ values were associated with softer gels. The type of gelling agent did not greatly affect the postautoclave $\mathrm{pH}$; mean values among gelling agents were within $0.05 \mathrm{pH}$ units. Postautoclave $\mathrm{pH}$ of MS medium was lower than that of WPM or GB. This study verifies the need to observe uniform sterilization protocols to maintain consistency in the chemical and physical properties of media.
\end{abstract}

Protocols for preparing plant tissue culture media routinely incorporate adding inorganic and organic nutrients, growth regulators, a carbon source, and frequently a gelling agent to support and orient the tissue. Medium $\mathrm{pH}$ is usually adjusted before adding the gelling agent. The gelling agent is added, and the medium is melted and dispensed into culture tubes or vessels for autoclaving. Alternatively, media are not melted before sterilization but autoclave in bulk amounts and dispensed when molten, particularly if heat-labile medium amendments are required or if nonautoclavable containers (such as disposable petri plates) are used. Autoclaving at $121 \mathrm{C}$ for 15 to $20 \mathrm{~min}$ is commonly indicated. Heat sterilization can induce profound changes in culture media components, including decomposition of heat-labile nutrients, reactions between sugars and amino acids, $\mathrm{pH}$ changes, and formation of toxic compounds (Hsiao and Bornman, 1989; Schenk et-al., 1991; Schrauwen, 197 1).

Medium $\mathrm{pH}$ has a pronounced effect on the growth of tissues in vitro and influences some plant developmental processes (Owen et al., 1991; Smith and Krikonan, 1990). The rates of heating and cooling, culture medium composition, and the sterilization temperature may affect poststerilization $\mathrm{pH}$ (Behagel, 1971; Owen et al., 1991). The response of cultured tissues to $\mathrm{pH}$ changes can be modified by other media components. For example, the $\mathrm{pH}$ optimum for adventitious bud production on cul-

Received for publication 3 May 1993. Accepted for publication 17 Dec. 1993. The cost of publishing this paper was defrayed in part by the payment of page charges. Under postal regulations, this paper therefore must be hereby marked advertisement solely to indicate this fact.

'Warnell School of Forest Resources, Univ. of Georgia, Athens, GA 30602-7273. tured needles of Sitka spruce [Picea sitchensis (Bong.) Carr.] decreased with increasing agar concentration (Selby et al., 1989). Sarma et al. (1990) found that even the method of adding agar influenced postautoclave $\mathrm{pH}$ values.

The type and concentration of gelling agent have been shown to affect the growth of tissues in culture. Examples include somatic embryogenesis in cucumber (Cucumis sativis L.) (Ladyman and Girard, 1992), shoot apical meristems in Norway spruce [Picea abies (L.) Karst.] (Romberger and Tabor, 1971), rooting of sweetgum (Liquidambar styraciflua L.) shoots (Lee et al., 1986), shoot proliferation and growth in crabapple [Malus baccata (L.) Borkh. $\times$ M. pumila var. niedzwetzkyana (Dieck) Schneid.] and pear (Pyrus communis L.) (Singha, 1982, 1984; Turner and Singha, 1990), numbers of shoots in apple (Malus domestics Borkh. ) shoot-tip cultures (Pasqualetto et al., 1986), and shoot growth and rooting in tobacco (Nicotiana tabacum L.) seedlings (Scherer, 1988). Vitrification of tis(Bornman and Vogelmann, 1984; Debergh, 1983; Pasqualetto et al., 1986; Turner and Singha, 1990; Zimmerman and Cobb, 1989).

In Sitka spruce, Selby et al. (1989) attributed enhanced organogenesis and elongation of shoots on media with relatively soft gels to better contact with the medium than in rigid growth regulators, and nutrients from the culture medium. Debergh (1983) showed that a reduction in the availability of cytokinins occurred as agar concentrations increased. The rate of cytokinin uptake by tissues was reduced by increasing medium rigidity (Bomman and Vogelmann, 1984). Owens and Wozniak (1991) attributed the responses to gel type and concentration in sugar beet (Beta vulgaris L.) sues can result from low concentrations of gelling agent or liquid medium cultures gels, and resultant improved uptake of water, leaf disks primarily to water potential differences; they identified matrix potential and expressibility of water from gel as factors that largely determine water availability from gels.

During routine culture experiments, we have noticed differences in gel strength dependent on the volume of medium autoclave (i.e., predispensed in test tubes vs. bulk autoclave, then distributed). Differences were more noticeable with certain types of basal salts, such as Murashige and Skoog (MS) medium (Murashige and Skoog, 1962). It was unclear whether the type of gelling agent was a contributing factor. This study was thus conducted to evaluate the effects of medium volume during autoclaving, gelling agent, and basal medium composition on gel strength and $\mathrm{pH}$ of gels obtained.

\section{Materials and Methods}

The effects of three basal media, three gelling agents, and three medium autoclaving volumes were studied. MS medium (1962), Woody Plant Medium (WPM) (Lloyd and McCown, 1980), and Gamborg B5 (GB) medium (Gamborg et al., 1968), all with 2\% sucrose, were used. Solidifying agents were Phytagar (Gibco Lab., Gaithersburg, Md.) at $0.8 \%$ (w/v), Bactoagar (Difco Lab., Detroit) at $0.8 \%(\mathrm{w} / \mathrm{v}$ ), and Gel-gro (ICN Biochem., Irvine, Calif.) at $0.4 \%(\mathrm{w} / \mathrm{v})$. Media were prepared by adding the appropriate major, minor, and $\mathrm{Fe}$ stock solutions and $2 \%$ sucrose to purified water from a Modulab analytical water purification unit (Continental Water Systems, Norcross, Ga.). The $\mathrm{pH}$ was adjusted to 5.7 with either $\mathrm{NaOH}$ or $\mathrm{HC} 1$. The appropriate gelling agent was added, and the media were heated on a stirring hot plate until melted. Media were dispensed in three volumes: 1000 $\mathrm{ml}$ in 2-liter beakers, $100 \mathrm{ml}$ in $250-\mathrm{ml}$ beakers, and $10 \mathrm{ml}$ in $25 \times 100$-mm test tubes for each basal salt and gelling agent. Media were autoclave (Amsco, Medallion Series, Erie, $\mathrm{Pa}$.) simultaneously in two loads in beakers and test tubes for $20 \mathrm{~min}$ at $121 \mathrm{C}, 2.9 \mathrm{MPa}$, then redispensed while still molten into containers for texture and $\mathrm{pH}$ measurements. There were four replications per 27 treatments in a completely randomized design. Data were subjected to analysis of variance procedures of the Statistical Analysis System (SAS Institute, 1988).

Gel strength. Following autoclaving, 30 $\mathrm{ml}$ of medium from each treatment was dispensed into individual $100 \times 15-\mathrm{cm}$ plastic petri dishes for texture measurements. There were four replications per treatment, with three petri dishes per replication. Firmness was measured with a Voland Stevens Texture Analyzer (Voland Corp., Hawthorne, N. Y.) using a 0.5 -cm-diameter, flat probe, $2 \mathrm{~mm} \cdot \mathrm{s}^{-1}$ penetration speed and 4-mm penetration distance. Measurements were made at four points in each petri dish, avoiding edge effects, i.e., in the center and at three places midpoint from the center and edge of each plate. Data were taken for penetration force in gram-force and converted to newtons. Values are an indication of the texture of a medium, with higher 
values representing media with greater gel strength.

Media $\mathrm{pH}$. After autoclaving, $10 \mathrm{ml}$ of each medium were dispensed into $22 \times 150$ $\mathrm{mm}$ test tubes and allowed to solidify. There were four replications per treatment, with three test tubes per replication. Media were homogenized with a Virtis tissue homogenizer (Virtis Co., Gardiner, N. Y.) for $15 \mathrm{sec}$ with $10 \mathrm{ml}$ of purified water from a Modulab analytical water purification system. The $\mathrm{pH}$ was measured with a Corning Ion Analyzer 150 (Coming Science Products, Halstead, Essex, U.K.).

\section{Results and Discussion}

Gel strength was influenced by gelling autoclave (Table 1). Phytagar gels generally had greater gel strength than Bactoagar gels, although both were used at $0.8 \%$ Gel-gro media were of intermediate strength at $0.4 \%$. Comparing agar sources, Debergh (1983) found that agar brand and concentration affected the solidity of gels; his results had a range of more than $40 \mathrm{~J}$ difference among agar strengths at a concentration of 10 g.liter ${ }^{-1}$. We used two agar-based gelling agents: Phytagar and Bactoagar. Differences in gel strength between the two may have been associated, in part, with the proportion of agarose in the agars, which affects gelling ability in agar gels. Agarose concentration varies with the species of red algae from which an agar is derived, as well as processing method (Matsuhashi, 1990).

Autoclaving volume had a pronounced and significant effect on gel strength in general, declining as volume of the vessel autoclave decreased (Table 1). Burger (1988) showed that solutions autoclave in smaller volumes are subjected to longer exposure times to higher temperatures; liquid volumes of 10 and 4000 $\mathrm{ml}$ differed by $40 \mathrm{~min}$ in their time to reach $121 \mathrm{C}$. In a study evaluating autoclave-induced medium toxicity, Sawyer and Hsiao (1992) found that media autoclave in smaller aliquots were more toxic than the same media autoclave in larger aliquots. Loss of medium gel strength may be associated with heating, at least for the two agar-based media, in which agent, basal medium, and volume of medium

gel strength declined with smaller medium volumes. Media solidified with Gel-gro differed from the two agar-solidified media (Table 1). Media autoclave in 10-ml volumes had greater gel strength. However, Gel-gro media consistently had stronger gels at the intermediate autoclave volume. Others have reported fundamental differences between gellan gum and agar gelling agents in embryo production, shoot proliferation, culture fresh weight, and vitrification (Lady man and Girard, 1992; Pasqualetto et al., 1986, Turner and Singha, 1990).

Formulation of basal salts significantly influenced gel strength (Table 1). This effect was particularly apparent with media using Phytagar, where there was a greater difference between treatments in texture values than with the other gelling agents. MS media were significantly softer than those formulated with WPM or GB in both the agar gelling agents. MS and GB media were significantly softer than WPM medium when solidified with Gel-gro. In addition, MS media were particularly sensitive to autoclave volume effects, where differences in gel strength between larger and smaller volumes were marked. In every case, gels formed from media autoclave in volumes of $10 \mathrm{ml}$ were less rigid than those autoclave at $1000 \mathrm{ml}$.

In a study of the effect of agar addition method on tissue culture media, Sarma et al. (1990) observed that gel strength of media that were autoclave twice (first to dissolve the agar and again after distribution into tubes) was lower than that of media prepared by any other method. Predissolving the agar on a stir hot plate or preautoclaving without other media nutrients resulted in more rigid gels. This result suggests that high heating in the presence of other medium constituents may be a factor affecting gel strength.

Qualitative differences in the ions present reportedly affect gelation of agar gels: $\mathrm{K}^{+}$, $\mathrm{SO}_{4}^{-2}$, and $\mathrm{Cl}$ promote gelation rate, whereas $\mathrm{NO}_{3}$ retards gelation rate (Matsuhashi, 1990). The concentrations of these gel-promoting and gel-retarding ions in the media we used are MS: $27.4 \mathrm{~mm}$ and $39.4 \mathrm{~mm}$; GB: $27.8 \mathrm{~mm}$ and $24.7 \mathrm{~mm}$; and WPM: $21.1 \mathrm{~mm}$ and $9.7 \mathrm{~mm}$. The high retarding : promoting ion ratio in MS

Table 1. Effect of gelling agent, basal salts, and medium volume during autoclaving on gel strength as measured using a Voland Stevens Texture Analyzer. Data are for penetration force in millinewtons. Data are means of 48 observations.

\begin{tabular}{|c|c|c|c|c|c|c|}
\hline \multirow{2}{*}{$\begin{array}{l}\text { Gelling agent } \\
\text { and concentration }\end{array}$} & \multirow{2}{*}{$\begin{array}{c}\text { Basal } \\
\text { salt }\end{array}$} & \multicolumn{3}{|c|}{ Volume (ml) } & \multirow[b]{2}{*}{ Mean } & \multirow{2}{*}{$\begin{array}{r}\text { Grand } \\
\text { mean }\end{array}$} \\
\hline & & 10 & 100 & 1000 & & \\
\hline Phytagar & MS & 134 & 182 & 210 & $175 \mathrm{c}^{\mathrm{z}}$ & \\
\hline \multirow[t]{3}{*}{$0.8 \%$} & WPM & 236 & 295 & 312 & $281 \mathrm{~b}$ & \\
\hline & GB & 299 & 323 & 352 & $325 \mathrm{a}$ & \\
\hline & Mean & $223 \mathrm{c}$ & $267 b$ & $291 \mathrm{a}$ & & $260 \mathrm{a}$ \\
\hline Gel-gro & MS & 147 & 288 & 192 & $209 \mathrm{~b}$ & \\
\hline \multirow[t]{3}{*}{$0.4 \%$} & WPM & 220 & 330 & 266 & $272 \mathrm{a}$ & \\
\hline & GB & 159 & 256 & 216 & $210 \mathrm{~b}$ & \\
\hline & Mean & $175 \mathrm{c}$ & $291 \mathrm{a}$ & $225 \mathrm{~b}$ & & $230 \mathrm{~b}$ \\
\hline Bactoagar & MS & 78 & 135 & 241 & $151 \mathrm{~b}$ & \\
\hline \multirow[t]{3}{*}{$0.8 \%$} & WPM & 126 & 196 & 269 & $197 \mathrm{a}$ & \\
\hline & GB & 143 & 210 & 235 & $196 \mathrm{a}$ & \\
\hline & Mean & $116 \mathrm{c}$ & $180 \mathrm{~b}$ & 248 a & & $181 \mathrm{c}$ \\
\hline Grand mean & & $171 \mathrm{c}$ & $246 \mathrm{~b}$ & $255 \mathrm{a}$ & & \\
\hline
\end{tabular}

${ }^{2}$ Mean separation in columns or rows by Duncan's multiple range test, $P \leq 0.05$. medium may explain, in part, its lower strength compared to the other media. It is well established that cations and concentration influence the strength of gels of gellan gums such as Gel-gro (Sanderson, 1990). Divalent cations produce a stronger gel than monovalent cations at the same concentration. In the media we used, divalent cations are at the same concentration for WPM and MS, whereas $\mathrm{K}^{+}$ levels are much higher in MS than WPM. For $\mathrm{GB}$, the cation concentration is less than half that of MS medium; $\mathrm{K}^{+}$is about the same. Colloids are subject to destabilization by high salt concentrations, which may possibly contribute to the lower gel strength of MS medium.

In all cases, autoclaving resulted in a decrease in $\mathrm{pH}$, ranging from $\approx 0.2$ to $0.5 \mathrm{pH}$ units (Table 2). Numerous studies have likewise reported a drop in $\mathrm{pH}$ associated with autoclaving (e.g., Owen et al., 1991; Sarma et al., 1990; Selby et al., 1989; Singha, 1982). Singha (1982) found a decrease in medium $\mathrm{pH}$ of $\approx 0.5$ $\mathrm{pH}$ units; $\mathrm{pH}$ reduction was less pronounced with increasing agar concentrations. Selby et al. (1989) found that decrease in $\mathrm{pH}$ varied depending on the $\mathrm{pH}$ range used $(0.8$ to 0.9 of a pH unit at pH 6 vs. 0.1 to 0.2 of a pH unit at $\mathrm{pH} 4)$.

In comparisons within a gelling agent, MS generally exhibited a lower postautoclave $\mathrm{pH}$ than the other two media (Table 2). The $\mathrm{pH}$ of MS was significantly lower than that of WPM or GB solidified with Gel-gro or Bactoagar; in Phytagar-solidified media, the $\mathrm{pH}$ of MS was lower than GB. Although the pH of Phytagar and Gel-gro was significantly lower than that of Bactoagar when comparing overall means of the three gelling agents, mean postautoclave $\mathrm{pH}$ values were within 0.05 units. Such a small difference in $\mathrm{pH}$ among the gelling agents unlikely would directly cause differences in physiological growth of cultures, as medium $\mathrm{pH}$ has been shown to fluctuate widely with both storage and tissue growth (Owen et al., 1991; Sarmaet al., 1990; Skirvin et al., 1986). Marked interactions between basal media cornponents and carbohydrates, which may affect medium $\mathrm{pH}$, occur during autoclaving. Precipitation and dissolution of salts; neutralization or esterification of acids; hydrolysis of proteins, polysaccharides, and esters; reactions between carboxyl and amino groups; and polymerization or depolymerization of alcohols, aldehydes, and saccharides result in changes in $\mathrm{pH}$ values (Behagel, 1971). Precipitation and carbohydrate breakdown during autoclaving may form toxic compounds (Schenk et al., 1991).

Media volume showed variable effects on postautoclaving $\mathrm{pH}$. In the two agar-based gelling agents (Phytagar and Bactoagar), $\mathrm{pH}$ values mostly were lower with media autoclave in the smaller volumes (Table 2). The greater gel strength of Gel-gro media at the intermediate autoclave volume concurred with generally higher $\mathrm{pH}$ values for those samples. Selby et al. (1989) found that the rigidity of media solidified with the same agar concentration increased with $\mathrm{pH}$. However, the differences in $\mathrm{pH}$ that we obtained, although statis- 
Table 2. Effect of gelling agent, basal salts, and medium volume during autoclaving on medium $\mathrm{pH}$. The $\mathrm{pH}$ was adjusted to 5.7 before autoclaving. Data are means of 12 observations.

\begin{tabular}{|c|c|c|c|c|c|c|}
\hline \multirow{2}{*}{$\begin{array}{l}\text { Gelling agent } \\
\text { and concentration }\end{array}$} & \multirow{2}{*}{$\begin{array}{c}\text { Basal } \\
\text { salt }\end{array}$} & \multicolumn{3}{|c|}{ Volume (ml) } & \multirow[b]{2}{*}{ Mean } & \multirow{2}{*}{$\begin{array}{l}\text { Grand } \\
\text { mean } \\
\end{array}$} \\
\hline & & 10 & 100 & 1000 & & \\
\hline Phytagar & $\mathrm{MS}$ & 5.29 & 5.30 & 5.32 & $5.30 \mathrm{~b}^{2}$ & \\
\hline \multirow[t]{3}{*}{$0.8 \%$} & WPM & 5.27 & 5.31 & 5.34 & $5.31 \mathrm{~b}$ & \\
\hline & GB & 5.38 & 5.40 & 5.51 & $5.45 \mathrm{a}$ & \\
\hline & Mean & $5.31 \mathrm{c}$ & $5.36 \mathrm{~b}$ & $5.39 \mathrm{a}$ & & $5.35 \mathrm{~b}$ \\
\hline Gel-gro & MS & 5.19 & 5.26 & 5.33 & $5.26 \mathrm{c}$ & \\
\hline \multirow[t]{3}{*}{$0.4 \%$} & WPM & 5.35 & 5.43 & 5.37 & $5.38 \mathrm{~b}$ & \\
\hline & GB & 5.37 & 5.50 & 5.41 & $5.42 \mathrm{a}$ & \\
\hline & Mean & $5.30 \mathrm{c}$ & $5.40 \mathrm{a}$ & $5.37 \mathrm{~b}$ & & $5.36 \mathrm{~b}$ \\
\hline Bactoagar & MS & 5.26 & 5.32 & 5.40 & $5.33 \mathrm{~b}$ & \\
\hline \multirow[t]{3}{*}{$0.8 \%$} & WPM & 5.36 & 5.41 & 5.44 & $5.40 \mathrm{a}$ & \\
\hline & GB & 5.47 & 5.26 & 5.47 & $5.40 \mathrm{a}$ & \\
\hline & Mean & $5.36 \mathrm{~b}$ & $5.33 \mathrm{c}$ & $5.44 \mathrm{a}$ & & 5.38 \\
\hline Grand mean & & $5.33 \mathrm{c}$ & $5.36 \mathrm{~b}$ & $5.40 \mathrm{a}$ & & \\
\hline
\end{tabular}

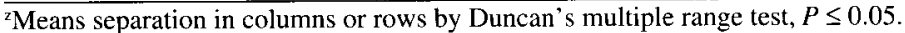

tically significant, were small. Values as affected by volume fluctuated within $\approx 0.2 \mathrm{pH}$ units. The observed $\mathrm{pH}$ differences may be contributory, but are unlikely to be the major causative factor in controlling gel strength.

Mean $\mathrm{pH}$ values of the different treatments varied from pH 5.19 ( $10 \mathrm{ml}$ MS solidified with Gel-gro) to $\mathrm{pH} 5.51$ (1000 ml GB solidified with Phytagar). Changes in $\mathrm{pH}$ near this magnitude have been shown to have a pronounced effect on cell differentiation in some culture systems. Morphogenesis of carrot (Daucus carota L.) somatic embryos was controlled by external $\mathrm{pH}$ of the culture medium. Cultures retained their morphology as preglobular stage proembryos at $\mathrm{pH} 4$, but developed into later embryo stages at $\mathrm{pH} 4.5$ or above (Smith and Krikorian, 1990). The growth of cultured buds of Sitka spruce and the incidence of vitrification were markedly affected by differences of $0.5 \mathrm{pH}$ units, when a range from $\mathrm{pH} 4.0$ to 6.0 was evaluated (Selby et al., 1989). In scarlet plume (Euphorbia fulgens Karw. ex Klostch) cultures, the optimal medium $\mathrm{pH}$ was 5.3 for shoot proliferation; lower $\mathrm{pH}$ values stimulated shoot growth (Zhang and Stoltz, 1989).

Effects of medium $\mathrm{pH}$ and gel strength on plant differentiation and development in vitro are well documented. We have shown that autoclaving can induce differential effects on gel strength and $\mathrm{pH}$, contingent on the type of basal salts, autoclaving volume, and gelling agent. In this light, it is apparently important to control autoclaving conditions carefully. This work verifies the need to observe uniform sterilization protocols, particularly within an experiment. For example, in studies where heat-labile substances may be added to some media (i.e., media components are bulk-autoclaved then combined before dispensing), it is important to sterilize all other media similarly. Likewise, physical changes and varying $\mathrm{pH}$ values in the culture medium should be considered as influencing factors in studies evaluating effects of basal salts or gelling agents on in vitro growth and development.

\section{Literature Cited}

Behagel, H.A. 1971. The $\mathrm{pH}$ and sterilization, p. 117-120. In: J. Van Bragt, D.A.A. Mossel, R.L.M.Pierik, and H. Veldstra (eds.). Effects of sterilization on components in nutrient media. Wageningen Press, Wageningen, The Netherlands.

Bornman, C.H. and T.C. Vogelmann. 1984. Effect of rigidity of gel medium on benzyladenineinducedadventitiousbud formation and vitrification in vitro in Picea abies. Physiol. Plant. 61:505-512.

Burger, D.A. 1988. Guidelines for autoclaving liquid media used in plant tissue culture. HortScience 23:1066-1069.

Debergh, PC. 1983. Effects of agar brand and concentration on the tissue culture medium. Physiol. Plant. 59:270-276.

Gamborg, O. L., R.A. Miller, and K. Ojima, 1968. Nutrientrequirementsofsuspension cultures of soybeanrootcells.Expt.Cell.Res. 50:150-158.

Hsiao, K.C. and C.H. Bommam 1989. Cyanideinitiated oxygen consumption in autoclave culture medium containing sugars. Plant Cell Rpt. 8:90-92.

Ladyman, J.AR. and B. Girard. 1992. Cucumber somatic embryo development on various gelling agents and carbohydrate sources. HortScience 27:164165.

Lee, N., H.Y. Wetzstein, and H.E. Sommer. 1986. The effect of agar vs. liquid medium on rooting in tissue-cultured sweetgum. HortScience 21:317-318

Lloyd, G. and B. McCown. 1980. Commercially feasible micropropagation of mountain laurel, Kalmia latifolia, by use of shoot tip culture. Proc. Intl. Plant Prop. Soc. 30:421-427.

Matsuhashi, T. 1990. Agar, p. 1-51. In: P. Hams (cd.).Foodgels. Elsevier Applied Sci., London.

Murashige, T. and F. Skoog. 1962. A revised mediumforrapid growth and bioassays with tobacco tissuecultures.Physiol.Plant. 15:473-497.

Owen, H. R., D. Wengerd, and A.R. Miller. 1991 Culture medium $\mathrm{pH}$ is influenced by basal medium, carbohydrate source, gelling agent, activated charcoal, and medium storage method. Plant Cell Rpt. 10:583-586.

Owens, L.D. and C.A. Wozniak. 1991. Measurement and effects of gel matrix potential and expressibility on production of morphogenic callus by cultured sugar beet leaf discs. Plant CellTissueOrgan Cult. 26: 127-133.

Pasqualetto,P.L.,R.H.Zimmerman,andI.Fordham. 1986, Gelling agent and growth regulator effects on shoot vitrification of 'Gala' apple in vitro. J. Amer. Soc. Hort. Sci. 111:976-980.

Romberger; J.A. and C.A. Tabor. 1971. The Picea abies shoot apical meristem in culture. L Agar and autoclaving effects. Amer. J. Bet. 58:131140 .

Sanderson, G.R. 1990. Gellan gum, p. 201-232. In: P.Harris(cd.).Food gels. Elsevier Applied Sci., London.

Sarma, K. S., K. Maesato, T. Hara, and Y. Sonoda. 1990. Effect of method of agar addition on post-autoclave $\mathrm{pH}$ of the tissue culture media. Ann. Bot. 65:37-40.

SAS Institute. 1988. SAS/STAT user's guide. Release 6.03 edition. SAS Inst., Cary, N.C.

Sawyer, H. and K.-C. Hsiao, 1992. Effects of autoclave-induced carbohydrate hydrolysis on the growth of Beta vulgaris cells in suspension. Plant Cell Tissue Organ-Cult, 31:81-86.

Schenk, N., K.-C. Hsiao, and C.H. Bomman. 1991. Avoidance of precipitation and carbohydrate breakdown in autoclave plant tissue culture media.PlantCell Rpt. 10: 115-1 19.

Scherer ${ }_{2}$ P.A. 1988. Standardization of plant micropropagation by usage of a liquid medium with polyurethane foam plugs or a solidified medium with the gellan gum gelrite instead of agar. Acts Hort. 226:107-114.

Schrauwen, PP. 1971. Sterilization kinetics, p. 4148. In: J. Van Bragt, D.A.A. Mossel, R.L.M. Pierik, and H. Veldstra (eds.). Effects of sterilization on components in nutrient media. Wageningen Press, Wageningen, The Netherlands.

Selby, C., R. Lee, and B.M.R. Harvey. 1989. The effects of culture medium rigidity on adventitious bud production and tissue vitrification in needleculturesofSitkaspruce [Picea sitchensis (Bong.) Carr.]. New Phytol. 113:203-210.

Singha,S. 1982. Influence of agar concentration on invitroshootproliferationofMalussp. 'Almey' and Pyrus communis 'Seckel'. J. Amer. Soc. Hort. Sci. 107:657-660.

Singha,S.1984.Influence of two commercial agars on in vitro shoot proliferation of 'Almey' crabapple and 'Seckel' pear. HortScience 19:227-228.

Skirvin,R. M., M.C. Chu, M.L. Mann, H.Y. Young, J.Sullivan,and T. Fermanian. 1986. Stability of tissueculture medium $\mathrm{pH}$ as a function of autoclaving,time,andcultured plant material. Plant Cell Rpt. 5:292-294.

Smith, D.L. and A.D. Krikorian. 1990. Somatic embryogenesis of carrot in hormone-free medium:ExternalpHcontrolover morphogenesis. Amer.J.Bet. 77: 1634-1 647.

Turner, S.R. and S. Singha. 1990. Vitrification of crabapple, pear, and geum on gellan gum- solidifiedculturemedium. HortScience 25:16481650 .

Zhang,B.and L.P. Stoltz. 1989. Shoot proliferation of Euphorbia fulgens in vitro affected by medium components. HortScience 24:503-504.

Zimmerman, T.W. and B.G. Cobb. 1989. Vitrification and soluble carbohydrate levels in Petunia leaves as influenced by media Gelrite and sucrose concentration. Plant Cell Rpt. 8:358-360. 